\title{
"For the women » - In Memoriam Simone Veil (1927-2017)
}

\section{Charles Barthold $^{1}$ (D) | Hervé Corvellec ${ }^{2}$ (D)}

\author{
${ }^{1}$ Department for People and Organisation, \\ Open University, Walton Hall, Kents Hill, \\ Milton Keynes MK7 6AA, United Kingdom of \\ Great Britain and Northern Ireland \\ ${ }^{2}$ Department of Service Studies, Lund \\ University, Box 882, 25108 Helsingborg, \\ Sweden \\ Correspondence \\ Charles Barthold, Department for People and \\ Organisation, Open University, Walton Hall, \\ Kents Hill, Milton Keynes MK7 6AA, United \\ Kingdom of Great Britain and Northern Ireland. \\ Email: charles.barthold@open.ac.uk
}

This In Memoriam presents the life of Simone Veil, an influential French politician, remembered for a law that made abortion legal in 1974. Simone Veil's contribution to the rights of women is featured as an instance of parrhesia (Foucault, 2011) that was able to establish a new regime of truth about the body, sexuality, and reproductive capacities of French women.

\section{KEYWORDS}

Abortion, Parrhesia, Simone Veil

Simone Veil, an iconic political figure of French post-war history died on 30 June 2017. Vibrant homages to her pioneering, courage, and rectitude have come from the entire political scope, except for the most conservative Catholics and extreme Right, who still condemn her legalization of abortion. Despite a long list of other achievements, for many French people her name evokes the law that depenalized abortion: the 1974 Voluntary Interruption of Pregnancy Act, known colloquially as Loi Veil (Veil Law). In an interview with Annick Cojean (2005), of the French newspaper Le Monde, Simone Veil declared that people remember this law; it is described in schools; people recognize her and beg her to come ahead of them in queues, or they come up to her spontaneously to thank her for what she did pour les femmes - for the women.

\section{1 | A LIFE IN THE $20^{\text {TH }}$ CENTURY}

As Anne Chemin (2017) notes, Simone Veil embodies three key moments of Western European $20^{\text {th }}$ century history: the Holocaust, the emancipation of women, and the construction of the European Union. One could even add decolonization.

Simone Veil (2007) was born Simone Jacob in 1927 in Nice, into an upper-class non-religious Jewish family with strict republican principles. Nice having passed under German control after the surrender of Italy in September 1943, she was arrested by the Gestapo in March 1944, the day after she had passed her Baccalaureate. She was deported with her sister and mother a week later to Auschwitz-Birkenau in Poland, from where they were forced in January 1945 on a 70-kilometer death march to an open coal car that took her several hundred kilometers to Bergen-Belsen in Northern Germany. She and her sister were liberated by British troops in April, but her beloved mother had died there of typhus in March. Her father and brother died at some unknown point during their deportation, and her other sister, who had been in the Resistance, survived Ravensbrück and Mathausen. As a symbol of her commitment to never allowing the Holocaust be silenced, Simone Veil never 
removed the number 78651 that had been tattooed on the inside of her arm at the concentration camp. Her son recounts her difficulties in speaking of these years, but she was often in short sleeves in the summer with her number clearly visible. When she entered the French Academy, she engraved "Birkenau 78651" on the front of her ceremonial épée (sword) and on the back, the French motto, Liberté, Egalité, Fraternité, and the European Union motto, In varietate concordia.

Returning to Paris, Simone Jacob gave proof to an imposing dynamism. She started higher education studies, taking law at the Sorbonne and legal studies at the Institut d'études politiques de Paris, Sciences-Po. At 19 she married Antoine Veil, with whom she rapidly had two boys, and a few years later gave birth to a third. Following the advice of her late mother, she was determined to have a professional career of her own to safeguard her economic independency. But because her husband opposed her desire to become an attorney, she settled for being a magistrate, passing the selective national examination to enter the judicial authorities in 1954.

After serving as a trainee in the Public Prosecutor's Department of the Paris court, Simone Veil joined the Department of Prisons, a notoriously misogynistic administration. Among other things, she worked at improving the condition of female prisoners from the Algerian National Liberation Front (FLN) who had been suffering torture, rape, and malnutrition in the French prisons of Algeria. In 1964 she moved to the Department of Civil Affairs, where she drafted an Adoption Law that clarified the right of children, restructuring and increasing professionalism in crèches (daycare services). She looked upon the May 1968 events first with benevolence, supporting the view of French youth that society was in urgent need of opening itself to Modernity; but she became more critical when the revolt drifted toward street violence. In 1970, Simone Veil became the first female General Secretary of the Conseil Supérieur de la Magistrature, the council that supervised the careers of judges and made recommendations to the president for staying the death penalty on convicted criminals. A year later, she was the first woman to join the board of ORTF, the office of French radio and television. In this position, she opposed the diffusion of Marcel Ophüls' (1971) film, The Sorrow and the Pity, which depicted extensive collaboration between the French population and Nazi German authorities. Contrary to the implicit thesis of the film, she contended, there were many French people who displayed exemplary solidarity with the Jews during the war.

Veil found herself at an equal distance between the Right and the Left-a nationalist Right, which vehemently opposed change, and a dogmatic Left fascinated by Marxism. Her political sympathy went with the Center-Right: the Mouvement Républicain Populaire (MRP), the Union pour la démocratie française (UDF), and Centre des démocrates sociaux (CDS), although she sometimes voted for the French Socialist Party. Unifying Europe and ending the colonization of Indochina and Algeria were two of her early concerns. Chemin (2017) describes her as European, liberal (in the European sense of the term), and open to social issues.

In 1974 Jacques Chirac, then Prime Minister of President Valery Giscard d'Estaing, asked her to become Minister of Health. Only $1.8 \%$ of members of the National Assembly were women; the Senate comprised $2.5 \%$ women; and Simone Veil was the first female to be a full minister in the Fifth Republic-indeed the first female minister since 1947. With an impressive career behind her, but no experience of the Ministry of Health, she accepted the position, which she held until 1979.

In 1979 Simone Veil was elected to the European Parliament for which she also became the first president, her appointment as a woman and a Holocaust survivor sending an incomparably strong message of equality and respect for human rights. A convinced promoter of European integration, with a particular interest in health and social issues, she became leader of the liberal group and remained a member of the European Parliament until 1993. While working on AIDS in Africa, she came back as a Minister of Health for two years, beginning in 1994. Later, in 1998, she was appointed to the French Constitutional Council, and elected to the French Academy in 2008. In 1996, she was one of the ten leading female politicians, five on the Left and five on the Right, who petitioned for parity: an equal representation of men and women in a country where, 50 years after having won the right to vote, women averaged no more than $6 \%$ of political positions at regional and national levels (Barzach et al., 1996). Simone Veil began retiring from public life in the 2000s, but occasionally manifested her fears about 
a repressive response to immigration. In 2007, she criticized President Sarkozy, whom she otherwise supported, for his idea of creating a Ministry of Immigration and National Identity, as if migrants were a threat to the French nation (Gurrey, 2007).

Simone Veil is buried beneath the Panthéon in Paris, along with such distinguished French citizens as Jean-Jacques Rousseau, the French abolitionist Victor Schœlcher, Victor Hugo, Emile Zola, André Malraux, and Marie Curie. There she rests with Germaine Tillion, another survivor of the concentration camps, ethnologist, member of the Resistance, and unyielding promoter of a duty of vigilance toward evil, with whom Simone Veil had collaborated on several occasions. Uncomfortable with militant and theoretical feminism, Simone Veil expressed a sense of solidarity with women, working pragmatically at promoting laws that reduce discrimination and inequalities.

\section{2 | THE VEIL LAW}

\section{1 | Context: French Feminism and abortion}

The passing of the Veil law legalizing abortion in 1974 would have been impossible without the struggle of the French Feminists of the 1960s and 1970s for the legalization of contraception and the depenalization of abortion. After the Neuwirth Law in 1967 had legalized contraception, and particularly the contraceptive pill, the attention of campaigners shifted toward a repeal of the repressive 1920 legislation, a repression that was largely directed at women without the financial wherewithal to procure an abortion.

The Mouvement Francais pour le Planning Familial (MFPF- ca: French movement for family planning), created in 1956, and often referred to simply as Planning, had staged a campaign in the late 1960s with the Association Nationale pour l'Étude de l'Avortement (ANEA - ca: National Association for the Study of Abortion) in favor of moderate legislative change that would make abortion legal to protect the mother's health, if the fetus were deformed, if pregnancy were the result of criminal violence, or if the family were too poor to support the child (Stetson, 1986). The 1968 student revolt gave new impulse to further change. Capitalizing on the combined collapse of the conventional housewife model and rise of female employment, the non-mix Mouvement de Libération des Femmes (MLF- ca: Movement for the liberation of women) made free contraceptives and abortion on demand parts of a new balance of power between women and men (Chaperon, 1995). This demand was efficiently relayed by the Mouvement pour la Liberté de l'Avortement et de la Contraception (MLAC Movement, a social movement for the freedom of abortion and contraception) with at least 15,000 male and female members and increasing support from Planning, openly challenged the authorities by facilitating abortion in France with the safe suction method of abortion invented by Harvey Leroy Karman, and organizing trips to England and the Netherlands - countries that had already legalized abortion. Characteristic of the MLAC was its application of the traditional vocabulary of the extreme Left on issues of exploitation and repression of, and solidarity with workers; a feminist discourse on the oppression of female sexuality; the need to dissociate sexuality and procreation; and demands for free access to contraception and abortion (Zancarini-Fournel, 2003). When lawyer Gisèle Halimi and author Simone De Beauvoir created the association Choisir (To Choose) in 1971, to obtain the legalization of abortion with costs covered by the French social security system, abortion had become a wellorganized feminist cause (Stetson, 1986). In April 1973, intellectuals such as Simone de Beauvoir and Françoise Sagan, and celebrities such as actresses Stéphane Audran and Catherine Deneuve and filmmaker Agnès Varda banded together with lesser known women to sign and publish the Manifesto of the 343, in which they each declared that she had had an abortion, in an open challenge to the authorities to prosecute them. This decisive manifesto was followed by another, in which hundreds of physicians openly declared having performed abortions, putting their right to practice medicine at stake. Some obstetric departments in public hospitals even started advertising orthogénisme, a code name for abortion services. 
The Bobigny court case of 1972 made clear the growing discrepancy between the legislation on the one hand, and public opinion and legal practice on the other. A 16-year-old who had become pregnant following a rape had admitted to the police that she had procured a back-street abortion with the help of her mother and three other women, being unable to pay the risk fee demanded by a gynecologist to perform this illegal act, which would have amounted to two months' salary. Yet the Court released her. Her lawyer, Gisèle Halimi, then turned the separate trial of the women who helped her procure an abortion into a political trial, with top names in the arts, medicine, politics, and media providing their support to the defendants, in an open challenge of the legitimacy of the 1920 law. Creating new jurisprudence, the judge declared two of the girl's procurers innocent and gave suspended sentences to the other two (Ministère de la Justice, 2012). The number of sentences for abortion fell from several hundred in 1971 to no more than a few dozen in 1973.

Anti-abortion activists had started to mobilize themselves as well, and right-to-life associations opposed any legal change. They leaned on the Conseil National de l'Ordre des Médecins (National Medical Association), challenging its members to favor life over death; on the Catholic Church, strong opposers of birth control, which the right-to-life groups perceived as having moral authority; and on nationalists, who saw risk of depopulation in a legalization of abortion - an argument that had been behind the 1920 legislation (Stetson, 1986; Veil, 2007). Yet several bills aimed at changing the 1920 legislation were prepared and presented to the National Assembly (Ferrand-Picard, 1982). Conservative politicians had drafted some of them - one inspired by the ANEA position that had been rejected in 1972, for example. Other, more ambitious bills were presented by the Socialist Party or the Communist Party, both of which saw abortion as part of their social projects. Consequently, in 1973, a new legislation on abortion was still a highly controversial but urgent matter, with thousands of women every year dying or suffering, in addition to the irremediable health and reproductive damage, of having used a catheter, knitting needle, or parsley stalk (Gauthier, 2004). The blame and shame associated with abortion was also a difficult burden for these women to bear as well. Simone Veil (2007) recounts that she had barely been appointed Minister of Health when her extremely conservative predecessor recommended that she rapidly change the legislation lest she arrive at the Ministry one day and find activists from the MLAC preparing an abortion in her office.

\subsection{A memorable speech}

The newly elected President, Valery Giscard d'Estaing, had put the liberalization of abortion on his electoral platform, and he gave the responsibility of introducing a new law to Simone Veil. As a woman and a magistrate, she was fully aware of the innumerable dramas created by illegal abortions. Determined to find a legal solution to what she considered an insupportable social and legal situation, she first introduced a bill that enlarged the right to contraception. Then she conducted a series of consultations with health professionals, religious representatives, Freemasons, philosophers, and members of parliament to map their positions on abortion. Her goal was to develop a text that would go as far as possible, and yet be passed as law.

In her introductory speech to the Assembly (Veil, 1974/2017a), Simone Veil stressed her goal of bringing a consensual solution to an unbearable drama for some 300,000 women every year and an unacceptable challenge of the legal authority of the State. Her goal was not to make abortion a right, but to depenalize a last-resort solution for unwanted pregnancy. Coming back several times to the need for restoring the openly flouted authority of the State, she framed her mission as a pragmatic effort to reduce injustice and women's suffering through a better match of law and practice. She carefully refuted the argument that legalization of abortion would endanger the demography of the country. And in front of a nearly all-male Assembly, she stressed her conviction as a woman that no woman happily resorts to abortion. Seeing abortion as a tragedy, she made it clear to members of the Assembly that abortion was also to remain an exception, an ultimate solution opened for women in distress. Information about abortion was made legal, but not incitements to abort. The decision to abort was to belong to women only, but women who wished to abort had to go through a mandatory procedure of medical, social, and psychological counseling and information that was to make them cognizant of the gravity of the decision that they were to take, inform them about the possibility of 
giving the child up to adoption, and possibly dissuade them to abort. An eight-day period of reflection was imposed, and a written request for abortion was required. The Veil Law even gave a prominent role of control to physicians and other medical professionals (Ferrand-Picard, 1982). Only physicians were allowed to perform an abortion, and those physicians opposing abortion were given the right to conscientious objection. From an economic perspective, medical fees for an abortion were to be capped. But because the cost of contraception had been formerly refundable through Social Security, it was also necessary to stress the difference between contraception and abortion. There was therefore to be no refund for the cost of abortion, an exception being therapeutic abortions and abortions for the most destitute of women.

The debate started on November 26, 1974, and lasted three days. It was fierce, full of hatred and chauvinist contempt. The term barbarie (barbarism) was used to discredit Simone Veil's proposal, which was compared to the bomb in Hiroshima and the Nazi's crematory oven. She found swastikas painted on her house. Anti-abortionists gathered outside the Assembly saying their rosaries; a member of parliament played the heartbeat of a fetus loudly in the auditorium of the National Assembly, another spoke of genocide, and yet another evoked a future of slaughterhouses for children. Several opponents suggested the alternative of replacing abortion with vague declarations on the possibility of developing social support to the most needy. And while many conservative and liberal members of parliament expressed their opposition to the legalization of abortion, members of parliament on the Left asked for a Social Security refund of abortion.

Simone Veil has since stressed on many occasions that she had no qualms about introducing that bill. Describing in her autobiography (Veil, 2007) how some comments gave her nausea, she also stressed how a well-known Catholic Member of Parliament opposed the project but voted for it out of compassion for women in distress. In an interview in 1987, she stated that she experienced the insults aimed at her under the debate as insults aimed at all women (Veil, 2017b). But closer to Creon than to Antigone, she never lost confidence in reestablishing the authority of the law while promoting social justice.

Eventually, the text was adopted, 284 to 189 , with a short majority among conservative and liberal votes, and all but one vote from the Socialist Party and the Communist Party. Once passed at the Senate, the law was promulgated on January 17, 1975.

\subsection{A key battle in a long struggle}

The Loi Veil was passed for a period of five years only. It was voted again in 1979 under the leadership of Yvonne Pelletier, after a strong mobilization of feminists in political parties, trade unions, and the media. By 1982 Yvette Roudy had included abortion in Social Security payments, and in 1993 Véronique Neiertz made it an offence to obstruct an abortion. Martine Aubry prolonged the period during which a woman could obtain an abortion to 12 weeks and that women under the age of 18 did not have to demonstrate "distress" in order to obtain an abortion under Social Security. A decree in 2002 authorized pharmacists to deliver morning-after pills free of charge for women under 18. Finally, in 2014, socialist politician Najat Vallaud-Belkacem introduced and saw passed a law suppressing the notion of "distress" from the law on abortion, authorizing women to interrupt unwanted pregnancies without having to justify their reason.

Simone Veil was never keen on the law bearing her name. First because the expression Loi Veil was first used by those opposing her project. Second, because the law was passed thanks to the work of many others, not least the members of Planning, MLF, and MLAC, all of which had shown that the repressive legislation from 1920 was ineffective, unfair, and obsolete.

\subsection{Simone Veil's legacy or the instauration of a new regime of truth}

By advocating the legalization of abortion, Simone Veil displayed "a courage of truth-telling" (Foucault, 2011, p. 85): an ethical action beyond political pressure and moral intimidation, prompted by the critical situation of 
300,000 women risking their health, their future reproductive ability, and even their lives every year, the positioning of thousands of physicians who openly challenged the legal and medical order, and the quandaries of magistrates who wondered how to apply the 1920 legislation. Her sturdy resistance to chauvinist insults and emotional pressure that confronted her before, during, and after the debate on her bill at the National Assembly turned her into a symbol of women's struggle for justice against an hypocritical establishment, which had deliberately ignored the social truth of illegal abortion and denied the right of women to a chosen and safe control of their ability to procreate. The discourses of male politicians at the National Assembly against the Veil Law constituted the epitome of hypocrisy, as no one at the time could ignore the widely publicized problems brought about by illegally performed abortions. Simone Veil (2007) provides a measure of this hypocrisy in her memoirs, in which she explains that many politicians in the close entourage of President Giscard d'Estaing were vividly aware of the problems surrounding abortion, yet ignored these problems and even opposed legislative change.

We see in Simone Veil's decisions and the actions regarding abortion an example of Foucauldian "ethics of truth" (Foucault, 2011, p. 124) or parrhesia: "free- spokenness [...] as modality of truth-telling" (Foucault, 2011, 2). Foucault develops this notion in the ethical turn he gave to his project of asking: "what practices and through what types of discourse have we tried to tell the truth about the subject?" (2011, p. 3). According to Foucault, "the individual constitutes himself and is constituted by others as a subject of a discourse of truth" and "presents himself to himself and to others as someone who tells the truth" through parrhesia (2011, p. 3). However, parrhesia is "fundamentally a political notion", which entails the problematization of "the question of the subject and truth from the point of view of the practice of what could be called the government of oneself and others" (Foucault, 2011, p. 8).

Simone Veil not only performed an ethics of truth. She contributed to the establishment of a new "regime of truth" for French women, in the sense of a new "system of ordered procedures for the production, regulation, distribution and circulation of statements" (Foucault, 1977, p. 14) about their bodies, their sexuality, and their reproductive capacities. The 1974 Veil Law on abortion came to emblemize a decisive turn for women's rights that had started a few years earlier and took several more decades to establish more fully. In this new regime of truth, women were given access to contraception and, if needed, to abortion. Of course, the Veil Law gave physicians a key role in controlling the determination of women to abort, this access was subjected to the medicalization (Barker, 1998) of a woman's body and the management of women's bodies had become a legitimate object of public policies (Petchesky, 1990). But, as demanded by the feminist social movement, women could start experiencing non-reproductive sexuality (Boltanski, 2004), and it became more acceptable to have a non-reproductive sex without being systematically shamed or considered a prostitute (Boltanski, 2004). It became easier and more socially acceptable for women to claim that their bodies belonged to them, or simply to act that way. And this change had major societal impacts. In the family sphere, the strategic place of marriage as a social institution was challenged as it became possible for women to live outside of marriage, to delay marriage, or to have children without marrying (Boltanski, 2004). In the work sphere, gaining control over reproduction, more than any other change in mores or legislation, has enlarged the possibility for French women to pursue studies and to have a professional career on conditions comparable to those of men. As a result, a massive and durable challenge of the subaltern position of women in work and organizational life has occurred (Bureau, 2005).

Abortion is a right that is virtually impossible to challenge in today's France. The Veil Law has contributed to a democratization of gender biopolitics in an indisputable and lasting way. But biopower (Stromer, 2010) has not disappeared, as one is reminded by ongoing debates about proof in cases of rape, a divorced man's right to children, sex-reassignment surgery, or medically assisted procreation. Biopower fights evolve; they do not disappear. A key trait of the Veil Law is that the parrhesiastic action of an individual - Simone Veil - and her discourse at the National Assembly is remembered as pivotal in the transformation of the regime of truth about female bodies. Public reactions at her death expressed that her discourse on 26 November 1974, has been the point a male-centered regime of truth was ruptured. It is beyond dispute that the passing of that law would not have been possible without her parrhesiastic 
courage, her ability to present an acceptable text, and the ability to create a consensus on the basis of her personality, which brought about durable social change. Yet, one should not forget that the Veil Law capitalized on the accrued energy of the feminist struggles of the 1960s and 1970s. As Pavard $(2014$, p. 6) puts it, one should celebrate Simone Veil, but one should not forget that the Veil Law is collective text: "the fight of a woman should not mask the struggle of women".

\section{ORCID}

Charles Barthold (1) http://orcid.org/0000-0002-3520-8210

Hervé Corvellec (10 http://orcid.org/0000-0001-7491-8816

\section{REFERENCES}

Barker, K. K. (1998). A ship upon a stormy sea: The medicalization of pregnancy. Social Science \& Medicine, 47(8), 1067-1076.

Barzach, M., Bredin, F., Cresson, E., Gisserot, H., Lalumière, C., Neiertz, V., ... Veil, S. (1996). Le Manifeste des dix. L'Express (1996, June 6). Retrieved 19 September 2017 from http://www.lexpress.fr/actualite/politique/le-manifeste-des-dix_ 492498.html

Boltanski, L. (2004). La condition foetale: Une sociologie de l'engendrement et de l'avortement. Paris: Gallimard.

Bureau, A. (2005). La Place de l'avortement dans la vie des femmes. In A. Bureau, F. Collin, C. Deloy, E. Dorlin, G. Fraisse, M. Jaspard \& J. Renne (Eds.), Féminisme II. 2005: Des femmes et du politique (pp. 38-41). Paris: Éditions de la Bibliothèque Publique d'Information. Retrieved 1 October from http://books.openedition.org/bibpompidou/1397

Chaperon, S. (1995). La radicalisation des mouvements féminins français de 1960 à 1970. Vingtième Siècle. Revue d'histoire, 48, Oct-Dec, 61-74.

Chemin, A. (2017). Mort de Simone Veil, icône de la lutte pour les droits des femmes. Le Monde (2017, June 30). Retrieved 26 September 2017 from http://www.lemonde.fr/disparitions/article/2017/06/30/mort-de-simone-veil-icone-de-la-luttepour-les-droits-des-femmes_5153554_3382.html

Cojean, A. (2005). Simone Veil raconte la loi sur l'avortement. Le Monde (2005, March 20). Retrieved 26 September 2017 from http://www.lemonde.fr/a-la-une/article/2005/03/20/simone-veil-raconte-la-loi-sur-l-avortement_384894_3208. html\#bCRmQMWPhYPh3bQu.99

Ferrand-Picard, M. (1982). Médicalisation et contrôle social de l'avortement Derrière la loi, les enjeux. Revue Française de Sociologie, 23(3), 383-396.

Foucault, M. (1977). The political function of the intellectual. Radical Philosophy, 17, 12-14.

Foucault, M. (2011). The courage of truth: Lectures at the Collège de France, 1982-1983. Houndmills: Palgrave Macmillan.

Gauthier, X. (2004). Quand avorter était un crime, Elle (2004, September 27). Retrieved October 13 from http://bib.muvs.org/ data/mvs_000101/volume_2.pdf

Gurrey, B. (2007). Simone Veil embarrassée par le "ministère de l'immigration et de l'identité nationale.» Le Monde (2007, March 16). Retrieved 26 September 2017 from http://www.lemonde.fr/societe/article/2007/03/16/simoneveil-embarrassee-par-le-ministere-de-I-immigration-et-de-I-identite-nationale_884157_3224.html

Harris, A., de Sedouy, A. (1971). (producers) \& Ophüls, M. (director), The Sorrow and the Pity. [Motion Picture] France: Télévision Rencontre, Norddeutscher Rundfunk \& Télévision suisse romande.

Ministère de la Justice (France) (2012). II y a 40 ans, le procès de Bobigny. Ministère de la Justice (2012, December 20). Retrieved 26 September 2017 from http://www.justice.gouv.fr/histoire-et-patrimoine-10050/proces-historiques10411/il-y-a-40-ans-le-proces-de-bobigny-24792.html

Pavard, B. (2014). Si je veux, quand je veux. Contraception et avortement dans la société française (1956-1979). Rennes: Presses Universitaires de Rennes.

Petchesky, R. P. (1990). Abortion and woman's choice. The state, sexuality, and reproductive freedom. New York. NY: Longman. Stetson, D. M. (1986). Abortion Law Reform in France. Journal of Comparative Family Studies, 17(3), 277-290.

Stormer, N. (2010) Mediating biopower and the case of prenatal space. Critical Studies in Media Communication, 27(1), 8-23.

Veil, S. (2007). Une vie. Paris: Stock.

Veil, S. (1974/2017a). VERBATIM. L'intégralité du discours de Simone Veil du 26 novembre 1974 sur I'IVG. L'Obs (2017, June 30). Retrieved September 26, 2017 from http://tempsreel.nouvelobs.com/politique/20170630.OBS1430/verbatim-l-integralite-du-discours-de-simone-veil-du-26-novembre-1974-sur-l-ivg.html. 
Veil, S. (2017b). « Le jour où je gagne la bataille de l'avortement », par Simone Veil. Paris Match (Republished 2017, June 30; originally published 1987). Retrieved 26 September 2017 from http://www.parismatch.com/Actu/Politique/Le-jour-ouje-gagne-la-bataille-de-l-avortement-par-Simone-Veil-1296860\#

Zancarini-Fournel, M. (2003). Histoire(s) du MLAC (1973-1975). Clio: Femmes, Genre, Histoire, 18, $241-252$.

Charles Barthold is currently a lecturer in Management at the Open University (UK). He did his PhD at the University of Leicester (UK) on Financialization and Deleuze. He has published on business ethics, financialization, and poststructuralism.

Hervé Corvellec is a professor of management in the Department of Service Studies, Lund University. His current research interests focus on ethics and on waste and sustainability.

How to cite this article: Barthold C, Corvellec H. « For the women » - In Memoriam Simone Veil (1927-2017).

Gender Work Organ. 2018;25:593-600. https://doi.org/10.1111/gwao.12232 